\title{
Estimating the Causal Relationship between Financial Development and Economic Growth in Nigeria
}

\author{
Nnachi Douglas Nwaonuma and Nnamani Celine Udude \\ Department of Economics, Ebonyi State University, Abakaliki
}

\begin{abstract}
The aim of this study is to estimate the causal relationship between financial development and economic growth in Nigeria covering the period of 1970 to 2012. This study attempts to include all the financial development indicators and explain their effects on economic growth proxied by real GDP. The study used an time series method of analysis of data and setting up over parameterized model to capture all variables relating to financial development, however, through simplification, a more encompassing parsimonious and interpretable model was obtained by dropping insignificant variables. The study used time series econometrics method and Augumented Dickey-Fuller test statistics to examine the stationarity status of the series. Also, Johansen cointegration and Granger causality test statistics were employed to check the long run equilibrium of the series and to determine the direction of causality between financial development and economic growth. Results show that all the series were stationary at first difference I(1); also, there exist a stable relationship between financial development and economic growth in Nigeria. The result also shows a uni-directional causal relationship between financial development and economic growth. Specifically, there is a significant pass through from domestic saving to economic. This implies that given the period of the study, financial development stirs-up economic growth. The study reveals that time deposits and foreign direct investment (FDI) contributed significantly to economic growth in Nigeria. However, credit to private sector (RPSC), domestic saving (RDSA) and real money supply (RMS) make very little contribution to economic in Nigeria.
\end{abstract}

Keywords: Economic Growth, Financial Development, Granger Causality, Nigeria

\section{Introduction}

The plan to achieving economic growth has preoccupied the policy thrust of all countries of the world. Nigeria as a developing country suffers the consequences of low level of economic activities evidenced by low productivity. In developed economies such as United States, Britain, Switzerland, Canada etc, evidence abound of the causal relationship between financial development and economic growth. However, for developing economies such as Nigeria, there is visible evidence of financial development and economic growth pass through. Akpan, (2007) findings conforms to this statement that there is weak correlation between financial development and economic growth of Nigeria's economy. The real sector of Nigerian economy, such as agriculture, manufacturing and construction which are the growth drivers of any economy are limping whereas the financial sector seem to be growing, even though the growth is not significantly robust. Notwithstanding, researchers in this field discern strongly that financial sector development holds significantly the key to economic growth. Schumpeter (1912) McKinnon (1973) and Shaw (1973) in what is termed Schumpeter and Mckinnon-Shaw hypothesis introduced finance variable into the growth factors. Adequate quantum of finance is needed to procure effective labour resources and new technologies to increase the output of goods and services. Traditionally, economists have identified such factors as capital, labour and technology as the major ingredients that lubricate the wheels of economic growth. Thus, improvement on them propels economic activities.

Furthermore, economic theories espouse a positive correlation between financial development and economic growth. Shaw (1973), Mckinnon (1973) Levine and Zervos (1996), Goldsmith (1969), Gregorio and Guiddou (1995) in a finance-growth hypothesis show convincing evidence of positive correlation between finance development and economic growth.

In Nigeria, empirical studies of Adelakun (2010), Odeniran and Udeaja (2010), Nkoro and Uko (2013), Osuji and Chigbuh (2013) and Anieken and Sikiru (2012) find evidence of positive relationship between financial development and economic growth.

However, some other studies report mixed and contradictory results on the nature of correlation. Some studies find negative relationship between finance development and economic growth. Deficiency in bank credit allocation to private sector negatively affects economic growth (Ayadi et al, 2013) and Venancio (2013)

Furthermore, conflicts exist among researchers in this field on the direction of causality of the variables under study; studies of Bangake and Eggoh (2011), Ahmed and Malik (2009) echo a pass through from financial development to economic growth. On the other hand, the studies of Candida (2013); Aye (2013); Checheti (2012), and Hurlin and Venet (2008) show that economic growth spurs financial development. Besides, Hassan and $\mathrm{Yu}$ (2011) finds a two-way causation between financial development and economic growth. 
Nigeria has been grappling with financial repression in spite of the series financial reforms. Before SAP, interest rate was low, credit to private sector was administratively controlled and directed to preferred sectors, loans and advances were directed to special sectors. Yet, the desired impact on economic growth was minimally achieved. The post SAP financial reforms that removed government interferences in the system still did not yield the desired objective of economic growth. Worst still the policy of banking sector consolidation that should have strengthened the capacity of the country's financial system to spur investment and economic growth is yet to meet the desired target.

Despite numerous financial sector reforms since independence, the Nigerian economy as well as the financial sector still grapples with growth. The financial development indicators are uncorrelated with economic growth. For instance, in 1970, 1973, 1977 the GDP stood at 11 per cent, 7 per cent and 8 percent and declined negatively to -7 per cent, -2 per cent and -1 per cent in 1978, 1982 and 1984. It has fluctuated except in 2002, 2003 and 2004 when it marginally increased from 10 per cent, 10.5 per cent and 10.9 per cent. Inspite of the policy of financial reforms the GDP growth rate of Nigeria could not be sustained, rather it declined to 6.5 per cent and 5.9 per cent in 2007 and 2008 respectively. It dropped again from 7.9 per cent to 7.4 per cent in 2010 and 2011 regardless of development of financial indices.

Major financial development indicators improved probably because of series of financial system reforms. For instance broad money supply as a ratio to GDP (M2/GDP) stood at 14.6 per cent in 1970 and increased to 21.8 per cent, 37.7 per cent 39.1 per cent in 1980, 2010 and 2011. Private sector credit as a ratio to GDP (PSC/GDP) increased from 6.7 per cent in 1970 to 10.9 per cent in 1980. It increased further to 13.5 per cent, 28.5 per cent, and 29.9 per cent in 2009, 2010 and 2011. Also, foreign direct investments (FDI) have not been stable and uncorrelated with growth. It increased from 46 per cent to 70 per cent in 1996 and 2002 and declined to 23 per cent and 17 per cent in 2009 and 2012.

Interest rate in Nigeria fluctuated within the period of this study even during the period of direct system of monetary control. Between the period 1970 and 1975, interest rate remained stable rate of 4 per cent and declined to 3.25 per cent in 1976 and 1977 and increased further to 10 per cent in 1985 and 1986. The average rate of interest fluctuated between 10 per cent and 15 per cent between 1986 and 2000. Investment growth within the period of this study seems not to be functionally related to rise in interest. For instance, investment to GDP increased from average 16 per cent in the 1970s to about 51 and 52 per cent in the early 80s and late 90s when interest rate increased from an average of 4 per cent to 10 per cent. It declined negatively to about -47 per cent, 50 per cent in 2003 and 2005 from 67 per cent in 2000. If declined negatively again from 36 per cent in 2007 to -10 per cent, and -11 per cent in 2009 and 2011.

Naturally, inadequate finance is an impediment to growth, it retards economic prosperity. Financial repression affects the production of goods and services. Finance is needed to procure new technologies and skilled labour resources that boost investment and output. Nigeria's financial system through several policies has evolved overtime with modest improvement.

In another perspective, decrease in economic activity is simply referred to as decrease in aggregate output and decline in income. Given a fall in income, aggregate demand for goods and services (capital and consumer goods) declines. Nigeria's low level of GDP may have negatively affected its finance development. Given the low demand of financial instruments occasioned by high margin interest rate exacerbated by low level of capital accumulation worsened the demand for capital goods.

Moreover, an empirical disagreement about the empirical direction of causality of financial development and economic growth has impeded policy direction. Thus, effective public policy that can significantly impact on the real sector to boost the material well being of the people of Nigeria is still elusive.

\section{Theoretical Literature}

Theoretical work in this field is limited. However, attempt has been made in this study to x-ray and review some of the theories in this field to give theoretical support to the study.

\section{Schumpter Theory of Finance Growth}

The correlation of financial development and economic growth has been copiously discussed by modern economists. Bagehot (1873), Schumpeter (1912) and Goldsmith (1969) were the early economists that advanced argument on the positive nexus between financial development and economic growth. They recognized the intermediation role of the financial sector as a channel in providing investible funds for economic growth. They argue that financial provisions were critical to technological progress as well as industrialization. This is plausible because effective direction and utilization of funds for the acquisition of new technology to replace inefficient techniques of production is germane for economic growth. Candida (2013) identified the channels through which the financial sector can enhance economic growth. First the financial sector mobilizes fund from surplus spending unit and canalizes it to deficit spending unit for investment purpose. Apart from domestic saving mobilization function, the financial sector offers access to international 
inflow of funds, to the domestic economy; this is done through the auspices of foreign direct investment (FDI), direct remittance, and foreign capital inflows. Providing adequate regulatory framework that assures proper allocation of funds to productive sectors and mitigating risks associated with Loans and advance uncertainties will also facilitate financial transmissions.

\section{Mackinnon-Shaw hypothesis of financial repression and economic growth.}

The works of Shaw (1973), Mackinnon (1973) referred to as Mackinnon- Shaw financial Liberation hypothesis argued that financial repression stifles economic growth. Lack of investible funds constraints access to physical assets and inadequate acquisition of new technologies stagnate economic growth.

Financial repression refers to saving apathy by the surplus spending unit caused by low interest rate. Low level of interest on saving discourages savers, thus reduces the volume of loan able funds for investors and reduces the acquisition of new and better production equipment for increase in output of goods and services and consequently economic growth. On the other hand, higher interest rate encourages savers to substitute the acquisition of physical asset (gold, diamond) for saving in brokerage forms. This increases the size of loanable funds required to sustain the financial requirement of the investing unit to acquire the needed technological impetus for economic growth and better living standard.

\section{King and Levine (1993) supply - leading hypothesis.}

The theory holds that causality runs from finance to economic growth. The theory also holds that financial development impacts positively on the economy. Improvements in financial sector and financial system indicators stirs-up economic activities. This is achieved through increased acquisition and accumulation of inventories, new techniques of production, etc that expand output of goods and services. Furthermore, efficient allocation of capital and attractive saving instruments stimulates mobilization of funds from surplus unit to deficit spending units.

\section{Robinson (1952) and Kuznets (1958) demand following hypothesis.}

This theory points at a uni-directional link between financial development and economic growth. The relationship runs from economic growth to financial development. Finance may expand given increases in economic activities. Economic growth spurs financial development through greater demand for financial services.

\section{Mutual dependency hypothesis}

Lewis (1995) postulates a bi-directional causality between financial development and economic growth. There is a feed- back effect between finance and growth. This implies that the development of the financial market indicators as a consequence of economic growth would in turn accelerate real growth ceteris parebus. The real sector may muster sufficient funds through household and business firms' savings that can deepen the financial sector. In the same vein, financial expansion deepens economic growth through efficient allocation and low risk investible funds to investment units.

\section{Mutual independent hypothesis (Lukas 1988)}

The theory posits that finance and economic growth may be mutually independent. Increase in finance may not propel economic growth and increase in activities in the real sector would also not induce financial development. Thus, there is no causality between finance and economic growth.

\section{Empirical Review}

There exists a large body of empirical literature in this study for both developed and developing countries as well as single -country and cross-country studies. There are two stands in this argument. Firstly, the empirical study that investigates the theoretical underpinning of the evidence of positive nexus between financial development and economic growth. Secondly, the direction of causality between financial development and economic growth.

The effectiveness and efficiency of a financial system and its impact on economic growth varies from country to country and most importantly from developed to developing economy. More developed financial systems are always common with more developed economy and vice versa. Recent empirical studies on developed countries for cross-country investigation by Levine and Zervos $(1996,1998)$ employed different econometric estimation technique with different data set for each work to evaluate the link between financial development and economic growth. Each research using different estimation method produces significant and remarkable results. Since, developed countries already have developed and stable financial system, their result showed strong positive relationship between financial development and economic growth. A well developed financial system remains a catalyst for a sustained economic growth. 
In a single country empirical analysis of Brirtish economy Greenwood and Javoniz (1990) Levine (1991), Bencivenga and Smith (1990) use ordinary least square (OLS) econometric estimation method and found a positive relationship between financial development and economic growth, Bagehot and Hicks (1999) also finds a positive relationship between financial development and economic growth using ordinary least square (OLS) technique of estimation in a single country study of British economy.

Empirical studies on developing countries by Mckinnon-Shaw (1973) in a separate and single study of South-east Asia, India and Pakistan finds a link between financial repression and economic growth, low saving shrinks economic growth; low level of financial development impacts negatively on economic growth. In a cross-country study of Lain American countries Roussean and Watchel (2005) uses data set ranging from 19602003 applying OLS estimation technique observes that instability in financial system and rapid liberalization affects the empirical relationship between financial development and economic growth, but note that efficient and effective financial sector produces a positive and strong nexus between financial developments and economic growth.

In the same vein, King and Levine (1993) studied 77 developing countries for a single period of 20 years (1960-1989) examined the link between financial development and economic growth. The study employs ordinary least square (OLS) estimation technique with four financial development indicators such as broad money assets in ratio to growth domestic product M2/GDP domestic money assets in deposit money banks divided by domestic assets of both deposit money bank and the central bank, private sector credits divided by GDP PSC/GDP, domestic credit to private sector divided by aggregate domestic credit, as explanatory variables. The study creates four growth indicators as the dependent variables. These include proxies such as average rate of growth in per capita GDP, average rate of growth in the capital stock of gross domestic investment. The research finds strong positive relationship between financial development variables and economic growth.

Ayadi et al (2013) study explores the relationship between financial development and economic growth using a sample of northern and Mediterranean countries within the period $1985-2009$. They employed panel data analysis and the result shows that credit to private sector and bank deposits are negatively associated with growth. The result also reveals that domestic investment and foreign direct investment (FDI) significantly contribute to economic growth. Venancio (2013) study of the relationship between financial development and economic growth, finds negative correlation between financial indicators and economic growth in developing countries who suffer inefficient credit allocations. The study employed modified OLS and the research covered the period of $1980-2011$ and $2000-2011$ for 17 and 19 countries respectively. This shows that some financial development indications are negatively related to growth given his findings.

Bangake and Eggoh (2011) deploy panel data methods and Granger causality on 71 countries for developed and developing countries within the period 1960 - 2004. The result shows bi-directional causality between financial development and economic growth across country.

Anieken and Sikiru (2012) in a study of banking sector credit and economic growth in Nigeria for the period 1970 - 2008 deploys two-stage least square estimation technique finds evidence of positive relationship between financial development and growth. The study also finds a uni-directional relationship, causality runs from growth to finance development. Also, Aye (2013), in an empirical study of the causal relationship between financial depending, economic growth and poverty in Nigeria. The study covers the period $1960-$ 2011. The technique of estimation is Johansen cointegration, vector error correction model and Granger causality test. The result shows evidence of unidirectional causality between economic growth and financial development, causality runs from growth to poverty conditional and finance.

Osuji and Chigbuh (2013) investigated the direction of causality between financial and economic development in Nigeria for the period 1960 and 2008. The work adopts Granger causality test statistics, cointegration, and error correction model on time series data. From the report, there is evidence bi-directional causality between finance and growth. There is mutual dependence of the variables of finance development and economic growth. Also, Odeniran and Udeaja (2010) in a study of financial sector development and economic growth in Nigeria from 1960 - 2009 uses a Granger causality test statistics to determine the direction of causality. The result shows bi-directional causality between some of the proxies of financial development and economic growth. There is empirical evidence of feed-back effect of finance and growth.

The result after estimation shows that there is no link between financial development and economic growth. Ukeje and Akpan (2007) in empirical study of single - country study on Nigeria for the period 19802006 to investigate the relationship between financial development and economic growth, the work employed time series econometrics, The results obtained shows that there exist a strong positive relationship between financial development and economic growth. Furthermore, the result finds a uni-directional causal relationship between financial development and economic growth. The direction of causality is from financial development to economic growth. Adeoye (2007) empirical findings differ from the output of Akpan and Ukeje (2007). His work does not find a link between financial development and economic growth. His study employs ordinary 
least square (OLS) estimation techniques, two proxies were used to capture the financial sector development: $\mathrm{M} 2$ as a ratio of GDP and banks credit to the economy as a ratio of GDP.

\section{Methodology}

The study is a time series data analysis of a single country limited to Nigeria. It uses ex-post factor design which explores cause and effect relationships, where data cannot be manipulated to the desire of the researcher. The data set used for the work covers the period 1970-2012. The data is culled from Central Bank of Nigeria (CBN) statistical bulletin of 2012, Vol. 22 In this study the dependent variable is GDP, whereas the independent variables are the financial development indicators derived and suitable for a shallow financial sector as mentioned in the theoretical Literature and supported by endogenous growth model. The variables are the ratio of broad money to GDP $\left(\mathrm{M}_{2} / \mathrm{GDP}\right)$; the ratio of domestic investment to GDP (INV/GDP), the ratio of private sector credit to GDP (PSC/GDP), the ratio of domestic saving to GDP (DS/GDP), real interest rate (r) as well as the error term $(\mathrm{Ut})$.

The unit root test used to test the stationarity condition of the time series data to avoid spurious regression. The Augumented Dickey-Fuller (ADF) was employed to reject or accept null hypothesis (HO) of the existence of unit root. The study also uses 5 percent (5\%) as the level of significance. Thus, if the p-value is less than $5 \%$ critical value, then the time series is stationary.

The annual data used for this study were standardized to the same base, except the GDP that is in million Naira, the independent variables have been reduced to ratios. The data series have been scrutinized to eliminate the influence of outliers in the series. The study also tests the long run relationship of the variables. More so, Granger causality test statistics was employed to test for the direction of pass through between financial development indicators and economic growth.

\section{Model Specification}

The Model for this work is anchored on the endogenous growth Model of Romar (1986) and Lukas (1988) which its theoretical underpinning emphasizes the role of financial development in economic growth, the production function is thus

$\mathrm{Y}_{\mathrm{t}}=\mathrm{AK}$

$\mathrm{Y}_{\mathrm{t}+1}=\mathrm{Ak}_{\mathrm{t}+1}$

Where $K_{t}$ is the capital stock at time $t$.

$\mathrm{A}=$ measures the sensitivity of capital that measures economic efficiency and the level of technological progress.

Since, economic growth is a function of liquidity provision for technological progress and industrialization, the financial development indicators (broad money ratio to GDP, the ratio of domestic investment to GDP, the ratio of credit to private sector to GDP, the ratio of domestic credit to GDP and real interest rate. This is expressed in a mathematical equation below:

$\mathrm{Y}=\left(\mathrm{M}_{2}+\mathrm{INV}+\mathrm{PSC}+\mathrm{DMS}+\mathrm{LD}+\mathrm{FDI}+\mathrm{RINT}\right)$

$\mathrm{InY}_{\mathrm{t}}=\beta 0+\beta_{1} \mathrm{InM}_{2} / \mathrm{GDP}+\beta_{2} \mathrm{InDMInV} / \mathrm{GDP}_{\mathrm{t}}+\beta_{3} \mathrm{In} \mathrm{LDR} / \mathrm{GDP}+\beta_{4}$ In FD1/ GDP $\mathrm{PSC}_{\mathrm{t}} \mathrm{GDP}_{\mathrm{t}}++\beta_{5}$ In $\beta 6$ In $\mathrm{DMS} / \mathrm{GDP}_{\mathrm{t}}+\beta_{7} \mathrm{RINT}_{\mathrm{t}}+\mathrm{U}_{\mathrm{t}}$

Where $\mathrm{Y}=$ Economic growth for which GDP is used as Proxy.

$\mathrm{M}_{2} / \mathrm{GDP}=$ Broad money ratio to GDP.

DMS/GDP = Domestic saving ratio to GDP

$\mathrm{PSC} / \mathrm{GDP}=$ Ratio of credit to private sector to GDP

$\mathrm{DINV} / \mathrm{GDP}=$ ratio of domestic investment to GDP

LD/GDP = Loan deposit ratio to GDP

FDI/GDP = ratio of foreign direct investment to GDP

RINT $=$ Real interest rate .

$\mathrm{U}_{\mathrm{t}}=$ error term.

\section{Data Discussion}

In this study, real GDP measured in Nigerian naira is used as proxy for economic growth. Real GDP was calculated with the help of GDP deflator by deflating 2010-2011 as based a year. $\mathrm{M}_{2}$ which is broad money is currency in calculation plus demand deposit $\mathrm{M}_{2}=\mathrm{CU}+\mathrm{DD}$ is obtained as a ratio of GDP, domestic saving ratio as a ratio of GDP, credit to private sector as a ratio of GDP, domestic saving as ratio to GDP, all these were obtained by dividing all the financial indicators each by the annual GDP, however, real interest rate was obtained by dividing nominal interest by inflation rate. The data for the study is taken from CBN statistical bulletin (2012). 


\subsection{Unit Root.}

\section{Result And Discussion}

Data for the period of the study 1970-2012 were subjected to stationarity test using the Augmented Dickey fuller (ADF) test statistics ( Dickey and Fuller !981). All thevariables are stationary at first difference and integrated I (1), consequently, a test of co integration was conducted to test whether there exist a long-run relationship between the variables understudy. This implies that if two or more time series are expressed to form an equilibrium relationship over the long run, even when the series are non- stationary, the will nevertheless move closely together over time such that the difference between them will be stationary.

Table 1: Augumented Dickey Fuller test Trend and Intercept (series at fist difference)

\begin{tabular}{|c|c|c|}
\hline Variable & ADF statistics & Order of integration \\
\hline RDINV & -4.661 & $\mathrm{I}(1)$ \\
\hline RDSA & -6.3903 & $\mathrm{I}(1)$ \\
\hline RFDI & -8.6383 & $\mathrm{I}(1)$ \\
\hline RGBP & -6.2036 & $\mathrm{I}(1)$ \\
\hline RINT & $-3,5628$ & $\mathrm{I}(1)$ \\
\hline RLD & -5.8772 & $\mathrm{I}(1)$ \\
\hline RNS & -6.3103 & $\mathrm{I}(1)$ \\
\hline RPSC & -5.6878 & \\
\hline
\end{tabular}

Source: Researchers computation

\section{Cointegration Test}

The Johansen's tests were conducted to test for Co integration. The results of the Co integration test are extracted and presented in table 2 .

Table 2: Johansen Co integration result

\begin{tabular}{|c|c|c|r|r|r|r|r|}
\hline \multicolumn{3}{|c|}{ Trace Test K=2 } & \multicolumn{4}{c|}{ Maximum Eigen values k=2 } \\
\hline Ho & Hi & तtrace & Critical value (5\%) & Ho & Hi & $\lambda$ max & Critical values (5\%) \\
\hline $\mathrm{r} \leq 0$ & $\mathrm{r}>0$ & 241.4397 & 159.5297 & $\mathrm{r} \leq 0$ & $\mathrm{r}>0$ & 107.5442 & 52.3626 \\
\hline $\mathrm{r} \leq 1$ & $\mathrm{r}>1$ & 133.8955 & 125.6154 & $\mathrm{r} \leq 1$ & $\mathrm{r}>1$ & 37.4180 & 46.2314 \\
\hline $\mathrm{r} \leq 2$ & $\mathrm{r}>2$ & 96.4773 & 95.7536 & $\mathrm{r} \leq 2$ & $\mathrm{r}>2$ & 33.2985 & 40.0775 \\
\hline $\mathrm{r} \leq 3$ & $\mathrm{r}>3$ & 63.1788 & 69.8188 & $\mathrm{r} \leq 3$ & $\mathrm{r}>3$ & 26.1688 & 33.8768 \\
\hline $\mathrm{r} \leq 4$ & $\mathrm{r}>4$ & 37.0099 & 47.8561 & $\mathrm{r} \leq 4$ & $\mathrm{r}>4$ & 22.0909 & 27.5843 \\
\hline $\mathrm{r} \leq 5$ & $\mathrm{r}>5$ & 14.9190 & 29.7970 & $\mathrm{r} \leq 5$ & $\mathrm{r}>5$ & 9.0030 & 21.1316 \\
\hline $\mathrm{r} \leq 6$ & $\mathrm{r}>6$ & 5.9159 & 15.4947 & $\mathrm{r} \leq 6$ & $\mathrm{r}>6$ & 5.8680 & 14.2646 \\
\hline $\mathrm{r} \leq 7$ & $\mathrm{r}>7$ & 0.0478 & 3.8414 & $\mathrm{r} \leq 7$ & $\mathrm{r}>7$ & 0.0478 & 3.8414 \\
\hline
\end{tabular}

$\mathrm{r}$ represents number of Co integrating vectors and $\mathrm{k}$ represents the number of lags in the unrestricted VAR model.

From results in table 2, the test statistics indicate that the hypothesis of cointegration, $\left(\mathrm{H}_{0}\right)$ among the variable is rejected. The results reveal that three cointegrating vectors exist among the variables of interest. Since the variables are cointegrated, there is therefore, a long-run relationship among the variables.

Table 3

\section{PARSIMONIOUS MODEL (FOR MODEL 1)}

Dependent Variable: DLOG(RGDP)

Method: Least Squares

Date: 12/24/13 Time: 10:01

Sample (adjusted): 19722011

Included observations: 40 after adjustments

\begin{tabular}{crrrr}
\hline \hline Variable & Coefficient & Std. Error & t-Statistic & Prob. \\
\hline \hline C & 0.112447 & 0.049432 & 2.274777 & 0.0326 \\
DLOG(RMS) & -0.430457 & 0.246161 & -1.748682 & 0.0937 \\
DLOG(RMS(-1)) & -0.069077 & 0.218668 & -0.315898 & 0.7549 \\
DLOG(RDINV) & 0.088423 & 0.038532 & 2.294807 & 0.0312
\end{tabular}




\begin{tabular}{lrrrr}
\hline & & & & \\
DLOG(RDINV(-1)) & 0.017943 & 0.032521 & 0.551750 & 0.5864 \\
DLOG(RPSC) & 0.504206 & 0.200779 & 2.511253 & 0.0195 \\
DLOG(RPSC(-1)) & -0.022177 & 0.196412 & -0.112913 & 0.9111 \\
DLOG(RDSA) & -0.832200 & 0.053352 & -15.59816 & 0.0000 \\
DLOG(RDSA(-1)) & 0.330322 & 0.200233 & 1.649682 & 0.1126 \\
DLOG(RINT) & -0.061762 & 0.108685 & -0.568261 & 0.5754 \\
DLOG(RINT(-1)) & 0.097357 & 0.114090 & 0.853336 & 0.4023 \\
DLOG(RLD) & -0.199779 & 0.126835 & -1.575107 & 0.1289 \\
DLOG(RLD(-1)) & -0.080669 & 0.152555 & -0.528785 & 0.6020 \\
DLOG(RFDI) & -0.023762 & 0.018925 & -1.255597 & 0.2219 \\
DLOG(RFDI(-1)) & -0.014522 & 0.021153 & -0.686528 & 0.4992 \\
DLOG(RGDP(-1)) & 0.355402 & 0.204482 & 1.738062 & 0.0956 \\
$\quad$ ECM1(-1) & -0.167533 & 0.075939 & -2.206142 & 0.0376 \\
\hline \hline & 0.945023 & Mean dependent var & 0.129389 \\
R-squared & 0.906778 & S.D. dependent var & 0.339622 \\
Adjusted R-squared & 0.103694 & Akaike info criterion & -1.398123 \\
S.E. of regression & 0.247308 & Schwarz criterion & -0.680349 \\
Sum squared resid & 44.96246 & Hannan-Quinn criter. & -1.138599 \\
Log likelihood & 24.70976 & Durbin-Watson stat & 1.917660 \\
F-statistic & 0.000000 & & \\
Prob(F-statistic) & \multicolumn{5}{l}{} \\
\hline \hline
\end{tabular}

From the result of the parsimonious model presented in table 3, the result of the short-run dynamics error correction model of economic growth of Nigeria shows that the speed of adjustment from short run to long run is about 16 per cent. Also the parsimonious result which is simplified and interpretable indicates $\mathrm{R}^{2}$ value of 0.94 which means that all the variables can explain about 94 percent of economic growth. The F-statistics value of $2470(\mathrm{P}<0.05)$ shows that the variables are jointly significant. The Durbin- Watson value is approximately 2.0. This implies that the model conforms to the OLS assumption of no autocorrelation.

\section{Granger causality Test}

Table 4: Causality test results.

\begin{tabular}{|l|c|c|}
\hline Null hypothesis & P-values & Conclusion \\
\hline RMS does not Granger cause RGD & 0.7791 & Accepted \\
\hline RGDP does not Granger cause RMS & 0.3506 & Accepted \\
\hline RDINV does not Granger cause RGDP & 0.5653 & Accepted \\
\hline RGDP does not Granger cause RDINV & 0.0829 & Accepted \\
\hline RPSC does not Granger cause RGDP & 0.9625 & Accepted \\
\hline RGDP does not Granger cause RPSC & 0.0843 & Accepted \\
\hline RDSA does not Granger cause RGDP & 0.1567 & Accepted \\
\hline RGDP does not Granger cause RDSA & 0.0183 & Rejected \\
\hline RINT does not Granger cause RGDP & 0.4464 & Accepted \\
\hline RGDP does not Granger cause RINT & 0.8661 & Accepted \\
\hline RLD does not Granger cause RGDP & 0.9121 & Accepted \\
\hline RGDP does not Granger cause RLD & 0.6256 & Accepted \\
\hline RFDI does not Granger cause RGDP & 0.1989 & Accepted \\
\hline RGDP does not Granger Cause RFDI & 0.0822 & Accepted \\
\hline
\end{tabular}

From the test result in table 4, there is evidence of a causal relationship between one of the financial development indicators and economic growth. There is a uni-directional causality between economic growth proxied by RGDP and financial development. Specifically, the result shows a significant pass through from real domestic saving to economic growth.

\section{Conclusion}

The study aims at finding the impact of financial development on economic growth in Nigeria between the periods of 1970-2012 periods. It also aims at finding the causal relationship between this variable of interest. Financial development indicators were used to determine their effects on economic growth. The empirical result shows evidence of uni-directional causality between economic growth and financial development. The relationship runs financial development to economic growth. 
Flowing from the empirical findings of this study, the following recommendations are made as useful guide for policy makers and researchers. Since, real domestic saving cause economic growth, it is therefore pertinent to formulate policies that can encourage domestic saving thereby raising the requisite capital needed to stir economic activities in the country. This finding is in line with King and Levine supply-leading hypothesis. Government should formulate policies and empower institutions that can boost domestic investment. This can be achieved through increasing loans and credit s to the private sector.

\section{References}

[1]. Abdelhayidar, S. (2013). Potential financing sources of investment and economic growth in Nigeria: A Causality analysis Journal of Policy Modelling

[2]. Adelakan, O. J. (2010). Empirical study of financial sector development and economic growth. International Journal of Economic Development Research and Investment, 15 (2)218-236.

[3]. Ayadi, R.; Arabac E.; Ben-Naceur, S.; DeGroen, W. P.; (2013). Financing development, bank Efficiency and economic growth across the Mediterrianian, European Commission Research Area. vol. No 20.

[4]. Aye, G. C. (2013) Causality between financial depeening, economic growth and poverty in Nigeria. The business \& Management Review, 3(3).

[5]. Beck, T. (2009). The Econometrics of Finance and Growth. The Palgrave Handbook of Econometrics.

[6]. Beck, T.; Levine, R. and Loayza, R. (2000). Finance and sources of growth. Journal of financial development. 46 (1)

[7]. Bekaert, G.; Harvey - Campbell, R. and Christian, L. (2005). Does financial liberalization spur growth? Journal of financial economics.

[8]. Bengake, C. and Eggoh, J. (2011). Further evidence on finance - growth causality: A panel data analysis. Economic System.

[9]. Blanco, L. (2009). The Finance - growth link in Latin America. Southern economic journal.

[10]. Boulila, G. and Trabelsi M. (2002). Financial development and long-run growth: granger causality in a bivariate Structure, evidence from Tunisia. FSEGT Working paper.

[11]. Boulila, G. and Trabelsi, M. (2004). Financial development and long-run Growth. Evidence from Tunisia. Savings and Quarter \development journal.

[12]. Candida, F., (2013). Bank perfomance and economic growth: Evidence from granger panel causality estimations. Research Unit on Complex and Economics. Lisbon Portugal.

[13]. Chang, T. and Candill, S. B. (2005). Financial development and economic growth: Case of Taiwan. Journal of applied economics.

[14]. Checheti, S. and Kharrobi, E. (2012). Reassessing the impact of finance on Growth. Bank for Internal Settlement Working Paper. No 381.

[15]. Chigbuh, E. E. and Osuji C. C. (2012) An Evaluation of Financial Development and Economic Growth of Nigeria: A Causality Test. Kuwait Chapter of Arabian Journal of Business and Management Review 1 (10).

[16]. Christopolous, D and Tsionas, E. (2004). Financial development from economic growth: evidence from panel unit root, cointegration tests. Journal of development economics 73(1)

[17]. Dabos, M. P. and Gantman, E. R. (2010). The Fading Link? A. new empirical analysis of the relationship between financial development and economic growth. MFI working Paper Series.

[18]. Demirgue - Kunt and Levine, R. (2001). Regulations market structure, institutions and the cost of financial international. Journal of money, credit and banking: 427-431

[19]. Dickey, D. and Fuller, W. (1980). Distribution of the estimators for autoregressive time series with unit root. Journal of the American Statistics Association 74(1).

[20]. Engle, R. and Granger C. (1987). Cointegration and error correction: Representation, estimation and testing, Econometrics. $55(20)$

[21]. Goldsmith, R. W. (1969) Financial structure and development, New Haven: Yale University Press

[22]. Granger, C. and Newbold, P. (1974). Spurious Regression in Econometrics, Journal of Econometrics, 2(1).

[23]. Greenwood, J; Sanchez J. M. and Cheng, W. (2012). Quantifying the impact of financial development. Rochester Centre for economic research. Working Paper. No. 572 University of Rochester.

[24]. Hassan, M.; Sanchez B.; Yu, J. (2011). Financial development and economic growth: New evidence from panel data. The Quarterly Journal of Economics and Finance.

[25]. Helpman, E. (2004). The Mystery of economic growth. Harvard University Press.

[26]. Kuznets, S. (1995). Economic growth and income inequality. Ameriacn economic review. No. 45.

[27]. Levine, R., (2006). Finance and growth in Handbook of Economic Growth.

[28]. Levine, and Zervous, S. (1998). Stock market, bank and economic growth. American economic review 8: 537-58

[29]. Levine, R. (2003). More on finance and growth: More finance, more growth nexus, Review of Federal reserve bank of St Louis (85)4 31-46

[30]. Lewis, W. A. (1995). The Theory of Economic Growth. London. Allen and Union.

[31]. Liang, H. V. and Richert, A. (2007). Economic Growth and Financial Sector Development. Journal of Business and Research.

[32]. Liang, U. and Teng, J. Z. (2006). Financial development and economic growth: Evidence from China. China economic Review.

[33]. Lukas, R. (1988). On the mechanism of economic development. Journal of Monetary Economics, 22.

[34]. Mackinnon, R. I. (1973). Money and capital in economic development. Washington DC. Brooking Institution Press. 
[35]. Ndebbio G. E. (2004). Financial deepening economic growth and development: Evidence from selected sub-saharan African Countries AERC Nairobi Kenya. AERC Research Paper 142.

[36]. Nkoro, E. and Aham, K. U. (2013). Financial sector development-economic growth Nexus: Empirical evidence from Nigeria. American Journal of Contemporary Research 3(2)

[37]. Romar, P. (1990) "Endogenous technological Change". Journal of Political Economy (98)

[38]. Schumpter J. A. (1912). The Theory of economic development. An Enquiry into Profits, capital, interest and the business cycle. Cambridge. Harvard University Press.

[39]. Shaw, E. S. (1973). Financial deepening in economic development. New York: Oxford University Press.

[40]. Solow, R. (2001). Applying growth theory across countries: The World bank economic review. 15 (2)

[41]. Swan, W. (1956). Economic Growth and Capital Accumulation: The Economic Record, 32

[42]. Venacio, S. F. M. (2003). Does financial development promote economic development Economia Monteraria Financeira. University of Lisbon.

[43]. Wachtel, P. (2003). How much do we know about growth and finance? Federal reserve bank of Atlanta economic review, 88: 33-47 